This item was submitted to Loughborough's Research Repository by the author.

Items in Figshare are protected by copyright, with all rights reserved, unless otherwise indicated.

\title{
Derrida and photography theory
}

\section{PLEASE CITE THE PUBLISHED VERSION}

https://www.routledge.com/The-Routledge-Companion-to-Photography-Theory-1st-Edition/DurdenTormey/p/book/9781138845770

\section{PUBLISHER}

Routledge (Taylor \& Francis Group)

\section{VERSION}

AM (Accepted Manuscript)

\section{PUBLISHER STATEMENT}

This is an Accepted Manuscript of a book chapter published by Routledge in The Routledge Companion to Photography Theory on 20 November 2019, available online: http://www.routledge.com/9781138845770.

\section{LICENCE}

CC BY-NC-ND 4.0

\section{REPOSITORY RECORD}

Barnard, Malcolm. 2019. "Derrida and Photography Theory". figshare. https://hdl.handle.net/2134/22400. 


\section{Derrida and Photography Theory}

\section{Introduction}

There is a sense in which all Derrida's work has been about photography, and that it has all been the theory of photography, even if that sense is 'unfamiliar in the milieus in which a competent discourse on photography is practiced' (Derrida 2010b: 14). This is the sense in which Derrida's various accounts of the constitutive role of difference, delay and the absent in what is perceived and experienced as the identity and immediacy of the present is also an account of photography. What works for Derrida in the history of philosophy, in the analysis and deconstruction of the conceptual oppositions and binary logics of western thought also works in the theory of photography. As he says,

Ghosts: the concept of the other in the same, the punctum in the studium, the completely other, dead, living in me. This concept of the photograph photographs every conceptual opposition; it captures a relationship of haunting that is perhaps constitutive of every "logic" (Derrida 2007: 272).

That which is supposed to be dead and departed returns and lives on as a ghost or revenant to haunt and make possible the living present. And that which is supposed to be other and which is consequently excluded from the same, is present in that identity and makes it possible. We have seen Derrida make these moves and these claims with regard to such founding philosophical conceptual oppositions as writing/speech, expressive/indicative and nature/culture and we have become increasingly familiar with them. The history of philosophy supposed the dead letter of writing to be exterior to speech, 'a dangerous supplement', but Derrida demonstrated that its representational detour was interior to and a condition for living speech. What is less familiar are the ideas, first, that this haunting and this supplementarity is a conception of photography at all and, second, that this conception of photography photographs every conceptual opposition, capturing the haunting that makes every logic possible.

While it will not have time or space to show how this conception of photography captures the haunting that is constitutive of every logic or even how this conception of photography photographs every conceptual opposition, this essay will identify and explain the sense in which prosthetic supplementarity, 'the concept of the other in the same', is a conception of photography. It will show how some of the founding conceptual oppositions and some of the central debates of photographic theory can be explained in terms of this conception of photography. For example, it will outline Derrida's account of the way that the punctum, which is supposedly an instant and different from the studium, is actually a duration and thus thoroughly cultural. It will also show how, if the punctum is duration, it also allows technê 
or 'art/craft', and thus that, if all photography entails technê, then there is a point up to which all photography is art. The question as to whether or to what extent photography is art has occupied photography theory since the beginning, and not only through Benjamin's notion of aura. The conception of photography as document or documentary, and the relation of that conception to the rhetorical and ideological functions of photography are also raised by Derrida's critique of the supposed binarity of punctum/studium. If the punctum is duration, then there is time and space for cultural difference, ideology and rhetoric, and the integrity of any innocent documentary function is automatically compromised. And it will show how Derrida argues that the notion of aura, supposedly destroyed by technical reproduction, may be reinstated by exactly the technê that Benjamin alleges destroys it. In doing these things, it will explain how Derrida's work is a form of photography theory.

While he claim that all of Derrida's work has been about photography may appear contentious, (although I hope to demonstrate the sense in which it is true), the claim that all Derrida's work follows from his conception of time and temporality is surely not at all contentious. This much has been clear since the publication of Speech and Phenomena (La Voix and le Phénomène) in 1967, where he shows that Husserl is forced to suppress or ignore his initial profound insight into the constitutive role of the temporally non-present in the temporal present in order to make his phenomenological arguments work. This essay will explain Derrida's account of time and temporality before going on to show how that account is central to his photography theory and how it makes his critique of the punctum possible. It will then show the consequences of those arguments around the punctum for the theoretical debates concerning photography as art, the documentary or rhetorical functions of photography and finally how they paradoxically transform the notions of technê and aura as they are found in Benjamin's theory of photography.

\section{Derrida on Time}

In the chapter of Speech and Phenomena entitled 'Signs and the Blink of an Eye', Derrida introduces and takes apart the 'myth' of the punctual instant. This is a myth that we will meet again in his (2010b) Copy, Archive, Signature. Derrida argues that, as the blink of an eye has duration, closes the eye and introduces non-perception and absence as a condition of present perception (Derrida 1973: 65), so both the opening and closing of the camera's shutter and the punctum have duration and that duration introduces variation and difference as a condition of the identity of the instant (Derrida 2010b: 8-9). Derrida's account of time effectively consists in taking Husserl's radical re-thinking of time more seriously and applying it more rigorously and more consistently than Husserl does himself. 
In The Phenomenology of Internal Time Consciousness and Ideas, Husserl presents a conception of the present moment or instant in which that present moment is complicated by references to the past and to the future; the present is made possible by the relation to that which is not present. Husserl argues that the present contains protention and retention: he says that what makes the present moment possible is a relation to remembrance, which he calls retention, and to expectation, which he calls protention (Husserl 1975: 197-8 and 1964: 62). Every present perception that we have is coloured by or happens in the context of a relation to what we remember of past perceptions and to what we imagine or expect from future perceptions and Husserl argues that the present moment and the perception that takes place within it would not be possible without those relations. The presence of the present is thus conditioned or made possible by a relation to the other and the different (to what is by definition not present; the past and the future).

Derrida shows in this chapter that Husserl is forced to suppress or ignore the very insights that he has presented in his re-thinking of time in order to make other parts of his phenomenology work. For example, Husserl is committed to the idea of 'primordial dator intuitions' (Husserl 1975: 83). These primordial dator intuitions are foundational and authoritative perceptions and experiences: they provide incontrovertible evidence for his phenomenological investigations and, according to Husserl, they happen in 'the blink of an eye', in a punctual present instant. This, of course, is where Derrida locates the moment or the place at which Husserl's argument begins to self-deconstruct. Husserl is 'trying to retain two apparently irreconcilable possibilities': he wants to insist on both the punctual present that is needed for his dator intuitions to work and the construction of the present from the relation to what is necessarily absent (Derrida 1973: 67). It is clear that he cannot argue that there is a punctual 'now' in which fundamental intuitions may be had and that the 'now' is made possible by its relation to the not-now of protention and retention. However, this is what he is forced to do and Derrida has great fun identifying the points at which Husserl's text begins inevitably to creak under the strain.

Derrida's conception of time is thus based on his critique of Husserl's account of time in his (1967/1973) Speech and Phenomena. He insists on the constitutive role of the absent and the other in the supposed identity of the self-same present instant and, as I suggest, takes that Husserlian insight more seriously and applies it more rigorously and more consistently than Husserl does. The way that the alleged presence of the present is actually made possible by the relation to what is other than and different from the present (the past, memory or archive of retention, and the imagination, future or 'to come' of protention) permeates and structures all of Derrida's thought. It should come as no surprise, then that this conception of time is found almost unchanged in his accounts of photographic time to be found in his (2007) essay on the death of his friend Roland Barthes, and his (2010b) Copy, Archive, Signature. As 
suggested in the indented quote above, this conception of time may even be understood as a conception of photography and, as Husserl's re-thinking of time began the break with the Aristotelian conception of time (Derrida 1973: 61), so Derrida's conception of photography, based on that re-thinking of time, may signal the beginning of the end of 'a certain conception of photography' (Derrida 2010b: 5). In order to explain and support these claims, it is now time to consider the punctum and the studium.

\section{Time, Barthes, Punctum, Studium}

This complicated notion of time, in which what is other than and different from the present moment constitutes or makes possible that present moment, is the basis of Derrida's account of photography; as noted, it may even be photography. This notion of time is also the basis of Derrida's critique of Barthes' account of the punctum.

In his (1984) Camera Lucida, Barthes explains the punctum as the detail or element of a photograph that pierces him or wounds him, like the point of an arrow pricking his skin (Barthes 1984: 26-7 and 40-3). Throughout the text, Barthes identifies the puncta: in one photograph he sees only a boy's bad teeth, in another he concentrates on another boy's crossed arms and in a third he is pierced by the boy's huge collar and the girl's finger bandage. He distinguishes punctum from the studium, which is a kind of 'unconcerned', general or 'vague' interest in a photograph. Studium is the sort of interest in things that one finds 'all right', that is generated by one's membership of a culture and one which is therefore almost involuntary (Barthes 1984: 27-8). The punctum is an instant, a point, and it is presented by Barthes as existing outside of or apart from the culture that produces the studium. The studium, then, is coded, it is thoroughly cultural and it is even described as a form of connotation, or cultural meaning, by Barthes (Barthes 1984: 26, 51). The punctum is not coded, it is not a cultural product but an uncoded and even unnameable instant (Barthes 1984: 51).

Although he sometimes hints that Barthes actually experiences the same desire to hold two irreconcilable positions on the studium/punctum dichotomy as Husserl does in his account of time, (Derrida 2007: 272-3), and as we shall see in a moment, Barthes himself gives the game away at one point, it is nevertheless quite clear that the conception of photographic time supposed by the punctum is going to attract Derrida's attention. Derrida begins by observing that Barthes' interpretation of photography is governed by the 'logic of the punctual stigmê' and, with a reference back to Husserl's blink of an eye, he explains the instant or the prise de vue, of the photographic 'shot' as duration (Derrida 2010b: 8). As duration, the 'instant' is a 'heterogenous time', it supposes 'a differing/deferring and differentiated duration'. In this duration, then, difference has space and time to happen: 'the light can change...subevents can occur...micrological modifications [and] effects' can take place (Derrida 2010b: 8). If there is no present moment or 'atomic instant', 
then there can be no punctum: each supposedly atomic instant will have duration and one way in which this duration may be understood is as the temporal difference that Derrida insists on in Husserl's radical re-thinking of the structure of time. The differentiated duration is the complicated notion of time that we saw above, in which the 'to come' of a future and the archive or trace of a past are the conditions for the presence of the present.

There are various consequences of this argument and they are all relevant to photography theory. Put simply, this notion of the photographic instant or present as differentiated duration, as being constituted by the relation to the past and the future, to what is absent and not-present, explains the possibility of photography as art, as archive or documentary and paradoxically reinstates the possibility of a Benjaminian concept of a photographic aura.

\section{Photography as Art}

Debates as to whether and/or to what extent photography is art began in the nineteenth century, continue to this day and many of them revolve around precisely the issues that Derrida is concerned with in his account of photography. I will outline the general outlines and positions of these debates in order to support this claim, before explaining how Derrida's arguments are different from and more radical than those debates.

First, the issue of mechanical reproduction is used as grounds for two entirely different and opposed arguments in those nineteenth century debates. On the one hand, precisely because photography produces images that are mechanically produced, those images were understood as being free from the selections and subjective judgments inevitably generated by the human hand and the human eye. Photography was therefore valued and celebrated on the basis of the accurate, human-interference-free images that it produces. On the other hand, and for exactly the same reason, photography was deemed to fall outside the realm of art: because the images photography produces were mechanically produced, those inevitably and utterly accurate images were seen as forcibly removing or eliminating the artist's work in creating and composing or configuring the image.

In the first argument, it is the absence of the photographer's selections and judgments that cause the photographic work to be accurate, and therefore not art. In the second argument, it is the elimination of the presence and role of the artist's creative and compositional work that brings about the failure of photography to achieve artistic status. Judgment is like discrimination and it is to do with the evaluation of perceived differences, and composition and configuration are to do with constructing one arrangement of elements rather than another, different, arrangement. We have seen above that these ideas of difference and composition are exactly the ideas that Derrida also says determine the possibility and status of photography as art and/or not-art; this 
may be taken as more support for the argument that all Derrida's work is photography theory.

Second, David Bate points out that, in twentieth century debates about art and photography, a distinction arises between '"artists who use photography"' and '"photographers who aspire to art"' (Bate 2009: 135). He cites Keith Arnatt's gleeful ridiculing of the Tate Gallery's policy of showing photographs made by 'conceptual artists' but not showing 'work made by "photographers"' by pointing out that they appear to be happy to exhibit photographs made by 'artists who are photographers' but not to show photographs made by 'photographers who are artists' (Arnatt 1982, quoted in Bate 2009: 135). One of the presuppositions of the first statement, 'artists who use photography', is that there are people who are first of all artists but who then go on to use photography; their identity and existence as artists precedes their use of photography, which, it is implied, is initially or potentially separate and different from artists and their art. One of the presuppositions of the second statement, 'photographers who aspire to art', is that there are people who are first of all photographers but who aim to produce photographs that are art; their work is identified and exists initially as photography, which, it is implied is different and separate from art but which can achieve artistic status or become art. In these arguments, the distinctions between art and non-art and between photographer and artist are held to be clear and distinct but also to be thoroughly permeable in that non-art can turn into art (through aspiration) and artists can turn into photographers (through using the medium).

While the terms used to define and construct the debates around the artistic or non-artistic status of photography and photographers are very similar or even the same as those found in Derrida's account, his account of photographic time and his critique of the 'chrono-logic of the instant' (Derrida 2010b: 8) construct what may be considered a new or different explanation of both the terms and the debates in which they appear. If the instant is actually differentiated duration, then the time of the photograph becomes calculable; this means in principle that decisions and changes can be made within that time. Once one allows or admits photographic time as duration, what Derrida refers to as 'possible compositions... and recompositions' can be made, 'effects' can be introduced: in short, technê, a technics or, precisely, an art of photography becomes possible if not inevitable (Derrida 2010b: 9). These 'possible compositions....and recompositions' that Derrida notes cannot but remind us of the 'compositional creativity', the absence of which Price and Wells make the condition for photography not being art in the arguments noted above. Where the arguments above noted that the nineteenth century debates held the absence of the artist's creative work in composing the elements of the image to compromise or negate the artistic status of photography, on Derrida's account 'compositions...and recompositions' are necessarily part of the photographic punctum and to that extent, using the 
criterion of compositional creativity, photography is necessarily or inevitably art.

The situation described by Derrida in his account of the role of the punctum in generating or producing photography as art is quite different from the situation that Barthes describes. On Barthes' account, the instant of the punctum can only be a passive and recording instant, precisely because it is an instant; there can be no time or space in it for difference. If there is no time or space for difference then no decisions can be made and the punctum is entirely passive. As Derrida says, this point is the point at which 'the photographic act is not an artistic act' (Derrida 2010b: 9). If there is no time or space for decision in Barthes' version of the punctum, then the photograph cannot be art; without room or time for decision and at this point, it is simply a passive exposure. However, if as Derrida argues, there is duration and if that duration is 'constituted by a technê', then the entire photographic enterprise is 'undeniably marked' by that technê (Derrida 2010b: 10). This is to say that techne, guaranteed by duration, in turn guarantees some element of difference and thus decision in the photographic act and to that extent the photographic act is guaranteed to have at least an 'artistic' element.

If this is the case, if photography is necessarily art because the punctum is a duration and because duration introduces the possibility of compositional difference and thus decision, then the distinctions that Bate notices in twentieth century debates between '"artists who use photography"' and '"photographers who aspire to art"' (Bate 2009: 135) no longer obtain or apply. More accurately, the distinctions between art and non-art and between photographer and artist are no longer both clear and distinct and thoroughly permeable. On Derrida's account, all photographers are artists and all photography is art. On this account the absence of a temporally self-identical moment in the punctum is the condition for the photograph being art, and the photograph being art is the condition for the photographer being an artist. Similarly, if photography is inevitably art, then anyone who uses photography to make images is making art, whether they are called or consider themselves artists or not. And if photography is inevitably art then it is not for photographers to aspire to art or indeed to avoid it, they are necessarily always already doing it and to that extent they are necessarily always already artists.

\section{Photography and technê}

Derrida remarks that, having thought the entire photographic enterprise as undeniably marked by technê, we are now enjoined to 'rethink the essence of technê' (Derrida 2010b: 10).

Technê is an ancient Greek word, meaning something like art, or craft/craftmanship, referring to a human capacity to transform material. This 
material that is worked on and transformed by our human ability to make and to do is often, and most originally, conceived as nature and it is often presented as physis in Derrida's writing. Technê, from which we derive our sense and practice of technology and the technological, is classically conceived as being external to the body and perception and as something artificial, something added to an existing body or perception. The most obvious examples of such a conception of technological addition would be spectacles or replacement limbs. The spectacles are added to our body to enable us to see more clearly and the replacement limb is added to the body to enable us to walk, for example. Derrida's argument is that technê, the technological, is the condition for there being any body and any perception 'in the first place'. The technological is not a substitutive prosthesis, but rather a constitutive or 'originary' prosthesis, it is, (paradoxically), an addition that makes the thing to which it is added possible 'in the first place' (Derrida 2010b: 13).

One of the earliest and best-known examples of technê, of prosthetic technology, in Derrida's work, is writing. Supposedly a mere tool, an external and 'mechanical' form of representation that is added to speech as a supplement and which threatens the presence of living speech, writing is actually the condition for the presence of 'living' speech. The 'detour' into some form of external, written representation, is the condition for speech and speech could not exist or work without that originary tool or prosthesis. Another, equally early, but less well-known and potentially more controversial example of technê is perception. Derrida argues in Speech and Phenomena that 'perception does not exist' and that 'there never was any "perception"' (Derrida 1973: 45, 103) because perception must always be represented in some external system: 'the perceived present can appear as such only inasmuch as it is continously compounded with a nonpresence and nonperception, with primary memory and expectation (retention and protention) (Derrida 1973: 64). Representation in the form of memory and anticipation is the external and prosthetic condition for the possibility of what is called perception.

This is the basis of the sense in which Derrida is using the word technê. Consequently, when he argues that, in the punctum, there is duration and that that duration is 'constituted by a technê', and when he concludes that the entire photographic enterprise is 'undeniably marked' by that technê (Derrida 2010b: 10), this is what he is getting at. And this is why Derrida says in the essay on photography that perception is marked by techne, perception is dependent on 're-tention and re-presentation' by the technical and that there can be no 'pretechnical perception' (Derrida 2010b: 9). If this is the case, if there can be no perception that is not made possible by technê, then perception is itself a form of photography.

Barthes acknowledges an element of this understanding of the originary or constitutive prosthesis, and, as noted above, almost gives the game away 
regarding his uncertainty about the punctum. When he says that the punctum 'is an addition: it is what I add to the photograph and what is nonetheless already there' (Barthes 1984: 55), he is acknowledging that the punctum is a supplement. Saying that the punctum is what he adds to the photograph admits the cultural, his general interest, the interest he has as a member of a culture, to the punctum. The idea that the punctum is added conflicts with, or as Derrida has it, it 'composes with', the idea that the punctum is already there in the photograph, ready to rise out of the photograph and pierce him (Derrida 2007: 271). On Derrida's account, this is no longer a simple binary. The punctum is something added to a photograph but which is already there: the punctum is now more akin to Derrida's idea of supplementarity, of the originary or constitutive prosthesis that is an addition to something but which makes the thing possible by being added.

\section{Technê and aura}

One of the things we are also surely obliged or enjoined to rethink is the role of technê in the mechanical or technical reproduction of the photograph. This phrase is intended to recall Benjamin's essay on the work of art, the German title of which is Das Kunstwerk im Zeitalter seiner technischen Reproduzierbarkeit. It will be noted that the word in the title that traditionally or usually gets translated into English as 'mechanical' is technischen in the original German text. Technischen means 'technical', rather than 'mechanical', and this slightly different translation restores and authenticates the link made in the present essay to Derrida's use of the word technê.

Benjamin's argument in this essay is that aura in the work of art is destroyed by technical reproduction. The argument to be pursued in this section is that if, as Derrida says, the punctum is duration and if the duration of the punctum allows or permits technê, then there is a sense in which the uniqueness of the photograph is not destroyed by reproduction. Paradoxically, there is also a sense in which all works of art are technically reproduced and that therefore no works of art possess aura.

The argument in Benjamin's essay is that some works of art possess aura and others do not; more precisely, technically reproduced works of art do not possess aura. Aura is explained as the sense of uniqueness and authenticity that one feels before a work of art (Benjamin 1992: 217). Uniqueness has its source in the work of art's place in 'the fabric of a tradition'; the sense that there is a single unique work of art derives from the specificity of that work of art's location at a point in a tradition. Authenticity is a product of the work's place in ritual or cultic practices (Benjamin 1992: 214, 217). However, in the age of technical reproduction and for the first time, technical reproduction 'emancipates the work of art from its parasitical dependence on ritual' and 'to an ever greater degree, the work of art...becomes the work of art designed for reproducibility' (Benjamin 1992: 218). 
Technical reproducibility takes two forms in Benjamin's essay; woodcuts and lithography. Some eighty years after Benjamin wrote the essay, we may add electronic and digital forms of reproduction, but the effect is the same: the aura of the work of art 'withers' in the face of all such forms of reproduction. Reproduction destroys aura in two ways; by making possible many copies of the work of art and by making it possible for the work of art to 'meet the beholder' wherever they are (Benjamin 1992: 215). The existence of many copies of the work destroys the sense of the uniqueness of the work and the image meeting the beholder in their own 'particular situation' destroys the authentic cultic or ritual location of the work.

Benjamin has analogue photography and film in mind in this essay but it is clear that his arguments apply to electronic and digital forms of image and text production. The existence of the technically reproduced analogue or digital photograph in many copies, (or even in only potentially many copies), destroys the sense of the uniqueness of the work of art. The idea that any one of those many copies could come to meet us in our particular situation, wherever we happen to be, at any time of day or night, likewise destroys any possible sense of ritual or cultic value. Consequently Benjamin argues that technical reproduction destroys aura in the work of art.

However, if the punctum is duration and if duration is how or where technê gets in to the photograph and if technê is understood as the artistic alteration or formation of material, then there is a sense in which the work of art remains a work of art even after technical reproduction. It is this for two reasons or on two levels. First, there is the presence of artistic choice and decision-making, what Price and Wells called the 'selective discriminations' of the human hand and eye and the 'compositional creativity' of the artist in the production of the photograph. If the punctum as duration guarantees that these elements of technê get into the photograph then it is hard to deny the artistic (or crafty) components of photography and difficult to see how they could be destroyed by reproduction. Second, there is the sense of technê in technical reproduction. It is tempting to argue that the very means of reproduction guarantees some level of 'artistic' or creative content simply because technê is the transformation or working of material and each individual reproduction will by definition be different from the last and from the one to come. As the transformation or working of material, it is cultural and thus a form of cultural production, or 'art'. On this account, all technical reproduction is art.

The 'reverse' or negative of this argument would be to say that, if there is no non-technical, non-prosthetic perception, then all image construction, including all perception, is technical reproduction and no works of art retain aura. This argument uses Derrida's idea that there is no 'pretechnical perception' to make the point that all perception and all image making are 
forms or technical reproduction. No perception and no image-making have aura, because they are all the product of representation: some form of external representational system must have been used to (re)produce them 'in the first place'. They are all, to that extent and as Derrida says 'iterable', and none is the result of an 'un-iterable' experience; consequently, none is unique and none has aura (Derrida 2010b: 9).

The duration of the punctum may also be when and where the ritual and cult that Benjamin refers to get into the photograph. The creative decisions, along with the selections and discriminations of hand and eye are what make the work of art a work of art and Derrida argues that the time of the punctum is a durayoion and that change can occur withint it. Thus the things that make the work of art a work of art, which are inevitably connected with the rituals and cultic practices of the artist's studio - precisely the commonly fetishized discriminations and 'special' decisions that the artist makes - are present in the time of the punctum. If they cannot not be present, then there may be another reason for suggesting that the aura of the work of art is not destroyed by technical reproduction.

And if this time or differentiated duration of the punctum is when and where technics enter the photograph, when decisions and transformations may be made, when difference happens, then it provides the sense of Derrida's saying that 'The process here would begin before what is referred to as processing' (Derrida 2010b: 11). In the dialogue that makes up Copy, Archive, Signature, Michael Wetzel talks about how 'art...enters into the development process' of photography, when the photographer can change the decisions s/he has made about the length of time they allow for the image to develop, for example (Derrida 2010b: 11). In his reply, Derrida immediately suggests that this process of processing has always already begun: 'technics intervenes from the moment a view or shot is taken' and technics can involve the choice of viewpoint, the aperture and so on (Derrida 2010b: 12). It is not that the photograph is 'taken' and then the photographer begins the process of processing the image: the duration of the punctum ensures that the process has begun; it means that the process has always already begun.

In Copy, Archive, Signature, Derrida makes one or two final points concerning aura. At one point the discussion turns to the nineteenth and early twentieth century practice of presenting signed portrait photographs of oneself to people as gifts. Derrida speculates on the way in which the signature on the photograph (re)introduces something like authenticity to the image and on the way in which the signature and the portrait form and the fact that it is a gift (re)introduces something like uniqueness to the gift (Derrida 2010b: 22-3). There is no claim that Benjamin's destruction of the aura has been simply reversed or that aura is fully and unproblematically present in these photographs but the situation is said to bear witness to the 'irreplaceable fetish' of the 'absolute rarity', of the 'unique event' and thus the authenticity of 
the artwork (Derrida 2010b: 23). Later, Derrida refers to the phenomenon that everyone who has taught this subject to students will be familiar with: the attempt to reconstitute, rescue or recapture some element or vestige of aura from the personnel or processes of photography. Where students will insist that a photograph that was personally processed, developed or printed by the 'artist' still retains aura, Derrida refers to the photograph of Nietzsche's typewriter and the way in which it is used in biographies of Nietzsche. He says that 'an attempt is being made to reconstitute the aura around something that has or is bound have the effect of dispelling the aura' (Derrida 2010b: 29). Like the photographic negative, the typewriter is held to have some special connection to the person using it. The attempt is being made to reconstitute something like the cultic value around the photograph, (from which uniqueness and aura were held to derive in Benjamin's account), and that, if the typewriter was subsequently discovered not to have been Nietzsche's then 'it would no longer hold any interest' (Derrida 2010b: 29).

\section{Photographic archive and memory}

Notions of the archive and memory are clearly of central importance to much photography theory. The first chapter of David Bate's (2009) Photography is entitled 'History' and the relation between photography and memory is present from the first page. It is also interesting that Bate refers to the 'prosthetic' nature of the photographic representations that are held to constitute memory, to help us keep something and not lose it. He says, for example, that the portrait of a person 'stands in' for that person (Bate 2009: 9). The photographic representation stands for, or substitutes for, the person and representation is therefore conceived here in terms of one thing replacing something that is absent, or as one thing substituting for another thing. This conception of the relation between the photograph and the thing it is the photograph of are the origin of memory and an account or explanation of the archive. The photograph is an example of the substitutive 'prosthesis', where the photographic representation substitutes or stands in for the thing, the person, event, landscape or whatever that is now missing or lost.

However, on Derrida's account of the prosthesis, the prosthesis is not substitutive but rather originary and constitutive. The constitutive prosthesis is the supplement that is added; as noted above, it is, (paradoxically), the addition that makes the thing to which it is added possible 'in the first place' (Derrida 2010b: 13). So the photographic representation does not 'stand in' for the person; the photographic representation constitutes any and all representations we have of that person 'in the first place'. And this prosthetic structure works at the level of perception, as well as at the level of the photograph: Derrida comes close to arguing that perception is a version of photography. And this is because there is and can be no 'pretechnical perception' (Derrida 2010b: 9). 
Any pretechnical perception would depend on there being a punctum that was not duration, in which we were the entirely passive receivers of the material that comes through our senses. Derrida's argument, against Barthes, is that there is not a duration-free punctum, and thus that we are not simply passive receivers of whatever flows through the punctum. Because there is duration, we are 'active': because there is the inevitability of difference in duration, there is therefore active discrimination and decision on our part. This radically complicates the notion of active and passive as they apply to perception (and photography), and this is why Derrida casts around for neologisms with which to describe the new situation. He tries 'actipassivity' in Copy, Archive Signature (Derrida 2010b: 12) and he tries 'passactivity' in Athens: Still Remains (Derrida 2010a: 67).

This has consequences for the photographic theory of memory and the archive. If this entirely passive exposure that is supposed in Barthes' account of the punctum were possible, it would mean that an 'immediate and natural' perception, and an immediate archive' would be possible (Derrida 2010b: 10). However, because this entirely passive exposure is not possible, because there is duration and there is, therefore, both difference and decision, there can be no immediate, natural or (precisely) pre-technical, (pre-mechanical) perception. As Derrida argues in his (1996) Archive Fever, as well as here, this means that there can there be no immediate or unmediated archive or memory, each archive or memory has to be mediated and this can also happen only through representation and the trace, traces and representations of what has happened. This is why the prosthesis of memory is not the substitutive prosthesis as described in Bate (2009) but has to be the originary or constitutive prosthesis described in Derrida (2010b). It is also worth noting, very briefly, that because memory and archive can happen only through representation, they can happen only institutionally. One of the consequences of the debate between Derrida and John Searle in and following Derrida's (1977) is that it is now possible to understand representation as an institution. Searle agrees that the decision that $\mathrm{x}$ stands for or represents $\mathrm{y}$ is the first institution (Searle 1995) and following Derrida's arguments in (2010b) we can see that representation (as originary prosthesis) is necessary for any archive or memory to be made possible or, precisely, instituted - set up and established.

\section{The Photographic Image and Mourning}

The image, and the photographic image, are no different from any other form of the trace in Derrida's work, and this is another reason for arguing that all that work is photography theory. As Michael Naas says, 'every trace implies the death of its author not in some future present but already and structurally from the beginning ... death comes from the very beginning to work over all writing, all photographs, all traces' (Naas 2003: 1845). Every representation, every written, spoken or otherwise inscribed mark; every gesture, speech act, painting, drawing and photograph exists on the basis of or in relation to 
death, to that which is absent and not present. The most powerful of these absences or deaths, which make the iteration of inscription possible, is the death of the author. And it is the trace, the relation to the absent and nonpresent that precedes and makes any and all representation possible on Derrida's account. Derrida says that 'death, or rather mourning' opens up the possibility of the image and without an understanding of the role of death and mourning in the possibility of the image, 'one understands nothing of the power of the image' (Derrida 2001: 146).

What we have seen above as the living present in Husserl's work is fractured and put out of joint by the relation to the absent past and the future; any presence is therefore non-simple and complicated by the relation to the absent, or death. As Dick and Wolfreys point out, 'The ostensibly living present of phenomenology is no longer re-presented as such by the image, but called forth as the non-simple presence that, divided from originary presence and the living present, allows the thinking of its other' (Dick and Wolfreys, 2013: 272). For Derrida and Marin, this relation to the always already absent, to death, is the condition for the possibility of the image: it is death and mourning - the relation to the always already absent - that makes the image possible, that 'propels it to "vision"' (Marin, quoted in Derrida 2013: 146), or calls it forth. As Derrida says, 'only death, which is not, or rather mourning ... can open up this space of dynamis ... the possible as such' (Derrida 2001: 146) and make the image possible. The being, the condition, of the image is force and force is not a being, not part of ontology, and it is explained in terms of dynamis in Derrida's text.

On this account of the photographic image, death is not the simple absence of presence, the absence of something or someone that or whom was here but is no longer here: death as absence is now understood as constitutive of presence, of the living present - presence and the living present are only understood in relation to the constitutive role of absence or death within it. The image and the photograph have to be able to 'work' or be meaningful in the absence of the subject, the person who made the image or who took the photograph, the people in the image or photograph, as well as in the absence of any spectators of the image or the photograph. This is why Derrida tends to speak of reference, or even 'the referencial' rather than the referent (Derrida 2007: 288). The absence of the referent, death, is structurally presupposed, as a condition of any form of representation, it is not an accident that happens to the subject. Any system of representation has to be able to operate in the absence of any subjects: differences between elements and the relations between those different elements have to be in place but their being in place means that there do not have to be any subjects at all. The absence of the subject is one aspect of what is referred to as death here.

Consequently, if the image and the photographic image are understood as representation and if representation is understood as reproduction, as simple 
mimesis, (the resemblance of one thing to another thing) for example, then they are barely understood at all, according to Derrida and Marin. Or, rather, they are understood in the reductive terms of ontology and philosophy. This is because to understand the image and the photograph in this way is to miss the constitutive role of absence or death in the image and the photograph. On this account, the image relates to death insofar as it can represent, or reproduce, an image of someone or something who is no longer here (who is dead, maybe) but they cannot account for how death makes the image or the photograph possible in the first place. It is not that the photographic image simply represents someone who is or may not be here, poignant as this may be and, even with the famous Winter Garden Photograph of his mother, as Barthes describes it in Camera Lucida (Barthes 1984: 63ff). It is that the relation to death and mourning makes the photographic representation possible 'in the first place'. Death in the form of the absent subject is the condition of the image and of the photographic image: the contingent representation of subjects who will inevitably die or who are already dead is itself made possible by this more originary and structural form of death.

Recognising the role of death and mourning in the image and in the photographic image involves understanding how death and mourning take place 'in advance' and make the image as reproduction and mimesis possible. Rather than following the manifestation or coming to vision of the image, as much conventional photography theory would have it, they make the manifestation or appearance of the image possible. Derrida and Marin think that this accounts for the power or dynamis of the image: rather than being a 'weakened reproduction of what it would imitate', the image can now be thought and understood in terms of its power and its authority, in terms of what makes it possible (Derrida 2001: 147).

\section{Derrida's work is all photography theory}

The first sentence of this essay claimed that there is a sense in which all of Derrida's work has been about photography and that it is all photography theory. This is because there is something about photographic representation that is true of all representation, that is also true of conceptual, perceptual and linguistic representation. It was suggested that the notion of time provided the link here. The role of the past, the absent, or the dead was to make the present, the presence of the present and the living possible. The following quote was used in the opening paragraph to introduce these issues

Ghosts: the concept of the other in the same, the punctum in the studium, the completely other, dead, living in me. This concept of the photograph photographs every conceptual opposition; it captures a relationship of haunting that is perhaps constitutive of every "logic" (Derrida 2007: 272). 
A ghost is supposed to be dead and gone, but in Derrida's case that which is supposed to be dead and gone, which is supposed to have left or been excluded once and for all, is seen to have a constitutive or originary role in the present. Various aspects of the photograph and of photography were shown to share this structure or this economy: as well as the punctum/studium, there was aura, memory and archive. Derrida's critique of Barthes' concept of the punctum was shown to provide the key to these 'logics'. In Derrida's critique, there is duration in the punctum - that is where technê and art and culture (the studium) get in to the supposedly natural and passive instant from which they are believed to have been excluded

Consequently, the moment is fractured, time is 'out of joint', as Derrida says elsewhere (1994: 3) because there is a necessary and inescapable reference to past and future in the photographic 'instant'. The time of the present is out of joint because it necessarily contains and is complicated by the presence of that which is absent from it: as we saw with Husserl's account of time, each supposedly simple present instant is knocked out of joint by the parts played by the future and the past in making it possible. There is a paradox here in that (because of this disjointedness) the present instant is, or is able to present itself as, its own memory or archive, and it has to do this in an image or representation (one thing standing for another thing). It has to do this in an image, or representation, because there is nothing else. And because there is already a history, an available and re-iterable history of prior representations, we have to argue that the present is only what it is because of the archive, because of the trace, of what has passed (on) in it. Thus, as noted above, the supplement or originary prosthesis of the archive makes the present possible 'in the first place'.

This structure (or economy, as it is always changing) is the structure (economy) of the photograph as well as of representation, logic and thought, and this is why I have argued that all of Derrida's work is an account of photography. Because the structure of photography is and can be no different from the structure of any other form of representation, photography captures, or photographs every other logic, because every other logic will have to follow the logic of representation. These logics include the logics of friendship, hospitality, the gift and cosmopolitanism, as well as those of writing and the trace in Derrida's work. This is why Derrida says that the haunting/mourning that is photography is found 'everywhere' (Derrida 2007: 279). And this is why he says that 'the photograph photographs every conceptual opposition' and that it captures the relationship of haunting, (of one thing that is supposedly dead and gone actually being the condition for the living present) that constitutes every logic (Derrida 2007: 272).

\section{Bibliography}




\section{Primary Texts}

Derrida, J. (1973) Speech and Phenomena, Evanston, Northwestern University Press

Derrida, J. (1976) Of Grammatology, Baltimore, Johns Hopkins University Press,

Derrida, J. (1997, including 1988 'Afterword') Limited Inc, Evanston, Northwestern University Press

Derrida, J. (1978) Writing and Difference, Chicago, University of Chicago Press Derrida, J. (1987) The Truth in Painting, Chicago, University of Chicago Press Derrida, J. (1993) Memoirs of the Blind, Chicago, University of Chicago Press

Derrida, J. (1994) Specters of Marx: The State of the Debt, the Work of Mourning and the New International, London, Routledge

Derrida, J. 91996) Archive Fever: A Freudian Impression, Chicago, University of Chicago Press

Derrida, J. (1998) Right of Inspection, New York, Monacelli Press

Derrida, J. (2001) 'By Force of Mourning' in The Work of Mourning, Chicago, University of Chicago Press

Derrida, J. \& Malabou, C. (2004) "Athens and Photography: A Mourned-for Survival", in Counterpath: Travelling with Jacques Derrida, Stanford, Stanford University Press

Derrida, J. (2007) "The Deaths of Roland Barthes", in Psyche: Inventions of the Other Volume 1, Stanford, Stanford University Press

Derrida, J. (2010a) Athens: Still Remains, New York, Fordham University Press

Derrida, J. (2010b) Copy, Archive, Signature: A Conversation on Photography, Edited with an Introduction by Gerhard Richter, Stanford, Stanford University Press

Derrida, J. (2010c) “Aletheia”, Oxford Literary Review, 32: 2, 169-188

\section{Secondary Texts}

Barthes, R. (1977) Image-Music-Text, Glasgow, Fontana/Collins 
Barthes, R. (1984) Camera Lucida, London, Fontana

Bate, D. (2009) Photography: The Key Concepts, London, Bloomsbury

Benjamin, W. (1992) 'The Work of Art in the Age of Mechanical

Reproduction', in Illuminations, London, Fontana Press

Brenner, F. (2003) Diasporas: Homelands in Exile, Vol. 2 Voices, New York, Harper Collins

Brunette, P. and Wills, D. (1994) Deconstruction and The Visual Arts: Art Media, Architecture, Cambridge, Cambridge University Press

Dick, M-D. and Wolfreys, J., (2013) The Derrida Wordbook, Edinburgh, Edinburgh UP

Foucault, M. (1970) "Las Meninas", in The Order of Things, London, Tavistock Press

Husserl, E. (1964) The Phenomenology of Internal Time Consciousness, Bloomington, Indiana University Press

Husserl, E. (1975) Ideas: General Introduction to Pure Phenomenology, London, Collier Macmillan

Krell, D. F. (2004) "Shudder Speed: The Photograph as Ecstasy and Tragedy", Mosaic: A Journal for the Interdisciplinary Study of Literature, 37, 4, 21-38

Naas, M. (2003) Taking on the Tradition: Jacques Derrida and the Legacies of Deconstruction, Stanford, Stanford University Press

Naas, M. (2011) '"Now Smile": Recent Developments in Jacques Derrida's Work on Photography', South Atlantic Quarterly, 110; 1, Winter, 205-222

Richter, G. (2007) “Unsettling Photography Kafka, Derrida, Moses”, CR: The New Centennial Review, 7: 2, 155-73

Richter, G. (2010) “Between Translation and Invention: The photograph in Deconstruction", in Derrida (2010b) Copy, Archive, Signature: A Conversation on Photography, Stanford, Stanford University Press

Sartre, J-P. (2004) The Imaginary: A Phenomenological Psychology of the Imagination, Translated by Jonathan Webber, Abingdon, Routledge 
Wells, L. (ed) (Third edition 2004) Photography: A Critical Introduction, Abingdon, Routledge 